\title{
COMPARISON OF DISTANCE EDUCATION PROBLEMS DURING THE COVID-19 PANDEMIC
}

\author{
Vitalii Klochko $^{1}$ Tetiana Kulynych ${ }^{2}$, Natalia Chuiko ${ }^{3}$, Natalia Postolna ${ }^{4}$, Olena Holovanova ${ }^{5}$ \\ ${ }^{1}$ Department of Economics, Management and Administration, Kharkiv College of Trade and Economics of Kyiv National University of \\ Trade and Economics, Kharkiv, Ukraine \\ vitaliyklochko26@gmail.com \\ ORCID: https://orcid.org/0000-0003-4100-1838 \\ ${ }^{2}$ Department of Economics, Management and Administration, Kharkiv College of Trade and Economics of Kyiv National University of \\ Trade and Economics, Kharkiv, Ukraine \\ 163.kulinich@gmail.com \\ ORCID: https://orcid.org/0000-0002-6997-0537 \\ ${ }^{3}$ Department of Management, Economics and Marketing, Kharkiv State Zoological and Veterinary Academy, Malaya Danilovka, Ukraine \\ natasha_chuyko@ukr.net \\ ORCID: https://orcid.org/0000-0003-4100-1838 \\ ${ }^{4}$ Department of Economics, Management and Administration, Kharkiv College of Trade and Economics of Kyiv National University of \\ Trade and Economics, Kharkiv, Ukraine \\ ya.nataliya.postolnaya@gmail.com \\ ORCID: http://orcid.org/0000-0002-7283-5870 \\ ${ }^{5}$ Department of Economics, Management and Administration, Kharkiv College of Trade and Economics of Kyiv National University of \\ Trade and Economics, Kharkiv, Ukraine \\ ivanovaelena0912@gmail.com \\ ORCID: https://orcid.org/0000-0001-5409-9016
}

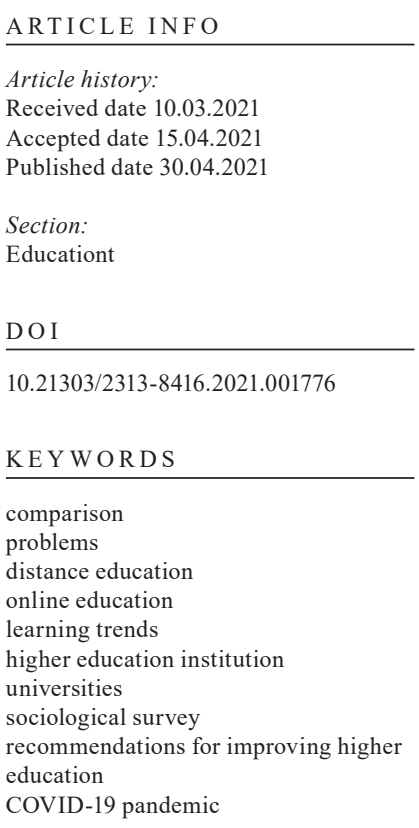

COVID-19 pandemic
ABSTRACT

The object of research: distance learning in higher educational institutions of Ukraine and the world during the COVID-19 pandemic.

Investigated problem: building a higher education system during the COVID-19 pandemic, capable of quickly adapting to adverse conditions and providing a high level of training.

The main scientific results: explored trends regarding the study of the impact of the pandemic on higher education, the effectiveness of distance education. Analyzed Ukrainian studies of distance education in universities. Held by students of the KNTEU Kharkiv Trade and Economic College. Based on the research results, conclusions and recommendations were made regarding the improvement of the quality of distance education in the field of higher education.

The area of practical use of the research results: higher education and professional education organizations.

Technological innovation: identified the problems of distance education during the COVID-19 pandemic, based on them, recommendations were developed to improve the quality of education in higher educational institutions of Ukraine.

Scope of application for technological innovation: practical activity in higher education and relations with stakeholders of educational organizations.

(C) The Author(s) 2021. This is an open access article under the Creative Commons CC BY license

\section{Introduction}

\section{1. The object of research}

The object of research distance education in the field of higher education during the COVID-19 pandemic.

\section{2. Problem description}

The pandemic has brought about significant changes in education throughout 2020 around the world. The vast majority of countries have closed all educational institutions for some time. According to UNESCO, as of April 2020, all schools closed in 191 countries of the world, where more than $90 \%$ of all students on the planet live. Ukraine has closed all educational institutions for visiting since March 12, 2020, when the epidemic began in the country and the first cases of the disease confirmed. By the Resolution of the Cabinet of Ministers No. 211 of March 11, 2020, quarantine was introduced throughout the country, and education applicants were banned from attending educational institutions of all levels. In particular, from May 25, it allowed to restore 
the work of kindergartens, and from June 1 - out-of-school education institutions and inclusive resource centers. Also, on June 1, practical training in vocational institutions and certain training events in higher education institutions resumed.

Since July 2020, an adaptive quarantine was implemented in Ukraine. By the Resolution of the Cabinet of Ministers of Ukraine No. 641 of July 22, 2020, depending on some indicators (dynamics of the number of patients, the number of beds in hospitals, etc.), each administrative-territorial unit decided to assign one of 4 statuses, which determined the degree of quarantine. By the Resolution of the Cabinet of Ministers of Ukraine No. 848 of September 16, 2020, it determined that the decision on the operation of educational institutions in the settlements of the «red zone» is jointly determined by the state and regional commissions on man-made and environmental safety and emergencies. From October 15 to November 15, the government recommended that institutions of higher and vocational education, due to the worsening epidemiological situation, completely switch to distance learning. On October 16, the Regulation on the updated conditions for organizing distance learning, developed by the Ministry of Education and Science of Ukraine, came into force. This document was a rather late response, as it was released more than a month after the start of the new school year and contained a brief description of the organizational processes of distance education. But it did not have enough methodological recommendations for conducting distance education for various types of institutions.

\section{3. Suggested solution to the problem}

The problems of adaptation of higher education due to the outbreak of the COVID-19 virus were considered in their works by some famous foreign scientists. All of them note that COVID-19 is causing major structural changes in higher education institutions. Owen P. Hall [1] writes that business schools are increasing their presence on the Internet as a temporary measure. Let's believe that the presence in the network will become permanent, including that of business schools. Brammer S., Clark T. [2] note the violation of the clarity and timeliness of feedback from stakeholders in higher education. Indeed, such violations are present, but they are not critical. Carrillo K., Flores M. [3] are convinced that it is necessary to go beyond the instrumental approach to teaching and learning on the Internet and include its ethical, political, and pedagogical dimensions in the equation. In our opinion, the greatest attention should be paid to pedagogical measurement, its adaptation to new changing conditions. De Boer H. [4] writes about the need for separate monitoring that will give an accurate picture of the impact of COVID-19. We are confident that monitoring should be carried out continuously and at all levels of higher education management. Nel K., Marais E. [5] have explored the possibility of teaching through WhatsApp or a similar platform. We believe that distance learning should not be limited to one platform, but include them as part of a whole.

An online survey among Ukrainian students and teachers of higher educational institutions of the Department of Political, Social, and Cultural Studies of the H. S. Skovoroda Kharkiv National Pedagogical University [6] revealed that the quality of distance education is not inferior to the quality of traditional education. Let's completely disagree with these conclusions, distance education can only serve as an addition to the traditional one, not replacing it. The Educational Ombudsman Service [7] has identified major challenges in providing quality education during a pandemic. We agree with this statement and believe that this problem can be resolved. The State Service for the Quality of Education [8] systematized the problems arising in the organization of distance learning during the quarantine period and affect the quality of education. Let's agree that the most important problem in distance learning in Ukraine is technical problems. Research by Stukalo N. and Simakhov A. [9] revealed that Ukrainian teachers did not have significant experience in online education. Let's believe that this problem is being solved by holding seminars among teachers.

The study aims to study the impact of distance learning on the training of specialists in higher educational institutions of Ukraine and develop recommendations for its improvement.

\section{Materials and methods}

During the study general scientific and practical methods were used: abstract-logical analysis and systematization of the process of identifying the nature of problems experienced by higher education during a pandemic. A quantitative study was carried out using a comparative statistical analysis of open data, as well as social studies conducted by the authors at the KNTEU Kharkiv Trade and Economic College in the period from March to April 2021. The study involved 50 students. 


\section{Results}

Biological and computer viruses have become an integral part of modern life. Humanity is forced to reconcile and adapt. The changes in our lives continue. Life changes primarily affect education.

Mark Agarkov [10] analyzed more than two hundred articles since the beginning of the pandemic on international platforms. He analyzed the content of 230 articles using content analysis. The vast majority of news is devoted to the world, Europe, the USA, and China. The experts were concerned about global and strategic issues. Seven aggregated topics: online learning, internationalization of higher education, quality of higher education, research, financial issues, strategic issues, interaction with the state. The popularity of online courses is growing. Some experts believe that a pandemic is both threat and opportunities. This opinion is typical of Chinese experts. Crisis and chance in China are denoted by the same hieroglyph. It is impossible to maintain the status quo in the post-like era. Higher education will expect to dominate by distance and online learning.

Owen P. Hall [1] explored how COVID-19 is shaping the future of education governance. He notes that many business schools have responded quickly to COVID-19 by increasing their online presence as a temporary measure in the short term. Some business schools offer online programs at prices that are 50 percent less than their traditional programs to stay competitive in the market. Today employers are looking for graduates who can quickly adapt to the changing conditions of society, aimed at solving problematic issues, as well as those who can skillfully operate on the Internet.

According to Owen P. Hall, business schools need to develop long-term relationships with like-minded educational institutions around the world who believe that students need to be taught in such a way that they will use for both business and society for a long time.

Brammer S., Clark T. [2], note that COVID-19 made significant changes in the clarity and timeliness of feedback from stakeholders, especially students and staff. The authors note that COVID-19 is leading to major structural changes in higher education institutions driven by competitive brand strengthening dynamics, changing student needs, the development and diffusion of new learning technologies, a decline in the number of international students, and the entry of large technology companies into the market, as well as the closure, amalgamation, and restructuring of universities due to funding cuts.

Carrillo K., Flores M. [3], studied the practice of teaching and learning on the Internet. They reviewed 134 empirical studies. They concluded that the key challenges in developing effective learning environments on the Internet were a precise pedagogical approach, appropriate and authentic objectives, and appropriate tools and technologies. They recognize the characteristics of online pedagogy. They concluded that more attention should be paid to the design of online learning; more attention needs to be paid to pedagogical problems that underlie cognitive achievement; further research is needed to assess the impact of integrated online learning pedagogy; more emphasis should be placed on educational experiences that are procedural and conceptual.

De Boer H. [4], noted that in 2020 the Dutch Education Inspectorate began collecting information on how education is adapting to circumstances due to the outbreak of the COVID-19 virus. They conducted a telephone survey at 23 universities. Online education was more concise: short lectures, fewer questions from students, and more complex teacher-student interaction. A university is a meeting place for people and ideas, but a virtual university will not be an attractive work environment.

Nel K., Marais E. [5], investigated a two-week hands-on teaching experience that 12 students who went through WhatsApp. Experience a workshop through WhatsApp or a similar platform that will meet the requirements of low cost, manufacturability, and accessibility for all partners.

March 2020, the Director-General of UNESCO, Audrey Azoulay, said that due to the COVID-19 coronavirus pandemic, more than 1.5 billion young people in 165 countries of the world can't attend classes due to the closure of general education institutions [11].

In 2017, David Goodhart published The Way To Somewhere, arguing that there is a political battle between the educated and cosmopolitan (Anywheres) and the low-paid and culturally conservative (Somewheres). Goodhart's new book, Head Hand Heart, expands on his analysis - targeting universities and the "bloated cognitive class" they have created. He claims the UK already has too many graduates who end up in low-paying jobs [12]. Australian Education Minister Dan Tehan has announced a major overhaul to ensure that universities "teach Australians the skills they need to succeed in the workplace of the future" [7]. 
March 2020, the Department of Political, Social, and Cultural Studies of the Skovoroda Kharkiv National Pedagogical University conducted an online survey among Ukrainian students and teachers of higher educational institutions. The survey was conducted on socio-economic issues during the coronavirus pandemic. The authors of the study identified the challenges and benefits of implementing distance learning. Disadvantages of distance learning: technical issues and psychological issues. Ukrainian teachers and students (according to the survey results) to the positive aspects of using distance learning note that the quality of distance education is not inferior to the quality of traditional education [6].

The following research was conducted by the sociological service of the Razumkov Center in cooperation with the Ilko Kucheriv Democratic Initiatives Foundation from July 3 to July 9, 2020, using face-to-face interviews at the place of residence of the respondents. About half of Ukrainians are negative about the introduction of distance education in connection with the pandemic, $32 \%$ of citizens supported this step. The most significant problems faced by our citizens in connection with the transition to distance learning are the decline in the level of academic performance of children (26\%), lack of attention of teachers to the needs of children during their studies (22\%), and technical problems: poor quality of the Internet $(21 \%)$ ) or lack of devices for online learning (19\%). The lack of technical means is noted by about $20-30 \%$ of citizens in small towns (up to 100 thousand inhabitants) [13].

The Office of the Educational Ombudsman in April 2020 (one month after the quarantine announced) conducted an online survey of parents and children studying in general secondary education. The purpose of the survey is to study the conditions for ensuring the rights of students to education during the quarantine. The Office of the Educational Ombudsman found that a third of parents $(27 \%)$ changed their attitude towards teachers in a positive direction, $19.3 \%$ noted a negative attitude. Distance learning has revealed serious organizational, educational, psycho-emotional, and technical problems related to ensuring the right to quality education. The following is noted: for a significant number of students, tasks are posted on the site, there is no communication with the teacher or the teacher is absent, competition between family members for technical equipment for distance work and learning. $32.5 \%$ of families of respondents have a partial or complete absence of technical equipment for remote interaction. Parents from rural areas were unable to actively participate in the survey due to the lack of Internet connection and equipment. The main difficulties and problems of distance learning during quarantine: organizational, and educational, psycho-emotional and technical [14].

April 2020, the State Service for the Quality of Education conducted an online survey of teachers, parents, and students of general secondary education institutions to study the conditions for ensuring the quality of distance learning in quarantine conditions. The authors of the study systematized the problems that arise during the organization of distance learning during the quarantine period and affect the quality of education: technical support for participants in the educational process; psychological, pedagogical, and methodological support of distance learning for students; sanitary and hygienic conditions for organizing distance learning. Based on the results of the study, the proposals of respondents to improve the organization of distance learning were systematized: to develop a free platform for distance learning for students; publish on the official website hygiene standards for online lessons; develop rules for participants in the educational process on distance learning (platforms, web resources, student assessments, the amount of homework) [8].

Research Stukalo N. and Simakhov A. [9] gave three main results: $86 \%$ of Ukrainian teachers did not have significant experience in online education before COVID-19; $80 \%$ of Ukrainian teachers consider themselves ready for online learning; $70 \%$ of students satisfied with the quality of online education at the university, although there are some difficulties and problems. Thus, Ukrainian teachers did not have significant experience in online education, but quickly responded and adapted to the changes.

Recommendations and suggestions for the online transformation of higher education in Ukraine are as follows:

- organize training courses for online education methodology for teachers;

- organize advanced training courses for online teaching methods for teachers of non-pedagogical specialties (including training in interactive online teaching methods, personality formation training trajectory, multidisciplinary online development courses); 
- the university administration must ensure constant monitoring of student satisfaction and teachers of the organization of online education for the accumulation of statistical data over time.

The authors surveyed at the Kharkiv Trade and Economic College of KNTEU. The following results were obtained (Table 1).

Table 1

Results of the student survey

$\begin{array}{cr}\text { Indicators } & \% \\ \text { What is your attitude towards distance education? } & 75 \\ \text { Positive } & 25 \\ \text { Negative } & \\ \text { How do you rate your learning in distance education? } & 35 \\ \text { Good } & 60 \\ \text { Satisfactorily } & 5 \\ \text { Badly } & \\ \text { Distance education problems: } & 37 \\ \text { Technical } & 51.9 \\ \text { Psycho-emotional } & 7.4 \\ \text { Organizational and educational } & 3.7 \\ \text { Sanitary and hygienic conditions for organizing distance learning } & 25 \\ \text { In your opinion, what is missing in distance education: } & 20 \\ \text { Technical support } & 15 \\ \text { Control of students' knowledge } & 20 \\ \text { Motivation to learn } & 20 \\ \text { Communication between students } & 12.5 \\ \text { Communication between students and teachers } & \\ \text { Study information by discipline } & \end{array}$

College students are positive about distance education (75\%). The majority of students believe that the mastery of academic subjects in distance education is satisfactory (60\%). Students note among the problems of distance education: technical (51.9\%), organizational and educational (37\%). According to college students, distance education is lacking: technical support (25\%), control of students' knowledge (20\%), communication between students $(20 \%)$, and communication between students and teachers $(20 \%)$.

\section{Discussion}

The study of the impact of the COVID-19 pandemic on the higher education system in the world and Ukraine makes it possible to conclude that it is necessary to study the impact of distance education on the level of training of specialists in higher educational institutions. In addition to the pandemic, a crisis is imposed in the university education itself, as the journalist, D. Goodhart writes about in the book "Way to Somewhere" [11] and the Australian Minister of Education Tehan D. [8]. In foreign scientific sources, much attention is paid to studying the impact of the pandemic on higher education, the effectiveness of distance education. Also, the popularity of online courses is growing.

Ukrainian studies of distance education problems have been reduced to an online survey of teachers, students and parents. COVID-19 has largely brought about major adjustments to the clarity and timeliness of feedback from stakeholders, especially students and staff.

The authors surveyed students of the KNTEU Kharkiv Trade and Economic College. The survey showed that there are problems in distance education. The main problem is technical. The proposals developed by the authors will be a topic for further research.

The proposals developed by the authors for improving distance education in higher educational institutions are fragmentary, conceptual in nature, and require consideration depending on the size of the educational organization, the crisis situation, and aspects of the activity. 


\section{Conclusions}

Biological viruses have become an integral part of modern human life. Ukrainians will have to live in a new reality, where distance education is becoming every day. In higher education in Ukraine, the dominance of distance and online forms of education is expected. Many of the innovations applied during the pandemic will benefit students after the crisis. Technology has come to the rescue and will continue to play a key role in educating future generations. Students of the college KNTEU Kharkiv Trade and Economic College have a positive attitude towards distance education (75\%). It should be noted that distance learning, even well-organized, can't completely replace direct communication with the teacher and in the team.

Based on the results of the study, let's recommend further paying great attention to studying the impact of distance education on the training of qualified specialists. First of all, let's propose to improve the qualifications of teachers to work with distance education. Next, constantly monitor the degree of satisfaction of students and teachers with online learning, identify problems and quickly solve them.

\section{References}

[1] Owen, P. H. (2020). Editorial: COVID-19 and the Future of Management Education. The Graziadio Business Review (GBR), 23 (1), 1-6. Available at: https://gbr.pepperdine.edu/2020/05/editorial-covid-19-and-the-future-management-education

[2] Brammer, S., Clark, T. (2020). COVID-19 and Management Education: Reflections on Challenges, Opportunities, and Potential Futures. British Journal of Management, 31, 453-456. doi: http://doi.org/10.1111/1467-8551.12425

[3] Carrillo, C., Flores, M. A. (2020). COVID-19 and teacher education: a literature review of online teaching and learning practices. European Journal of Teacher Education, 43 (4), 466-487. doi: http://doi.org/10.1080/02619768.2020.1821184

[4] De Boer, H. (2021). COVID-19 in Dutch higher education. Studies in higher education, 46 (1), 96-106. doi: http://doi.org/ $10.1080 / 03075079.2020 .1859684$

[5] Nel, C., Marais, E. (2020). Preservice teachers use of WhatsApp to explain subject content to school children during the COVID-19 pandemic. International Journal of Work-Integrated Learning, 21 (5), 629-641.

[6] Berezhna, S., Prokopenko, I. (2020). Higher Education Institutions in Ukraine during the Coronavirus, or COVID-19, Outbreak: New Challenges vs New Opportunities. Revista Romaneasca Pentru Educatie Multidimensionala, 12 (2), 130-135. doi: http://doi.org/10.18662/rrem/12.1sup2/256

[7] Tehan, D. (2020). National Press Club address. Available at: https://ministers.dese.gov.au/tehan/minister-education-dan-tehan-national-press-club-address

[8] Rezultaty opytuvannia shchodo dystantsiinoho navchannia v zakladakh zahalnoi serednoi osvity (2020). Derzhavna sluzhba yakosti osvity Ukrainy. Available at: http:/www.sqe.gov.ua/index.php/uk-ua/hovyny/1217-rezultaty-opytuvannia-shchodo-dystantsiinoho-navchannia-v-zakladakh-zahalnoi-serednoi-osvity Last accessed: 23.02.2021

[9] Stukalo, N., Simakhova, A. (2020). COVID-19 Impact on Ukrainian Higher Education. Universal Journal of Educational Research, 8 (8), 3673-3678. doi: http://doi.org/10.13189/ujer.2020.080846

[10] Samokhvalova, L. (2020). Liudyna merezheva i «zakryte» maibutnie: sotsiolohy pro svit pislia pandemii. Ukrinform. Multymediina platforma inomovlennia Ukrainy. Available at: https://www.ukrinform.ua/rubric-society/3154752-ludina-merezeva-i-zakritta-majbutnogo-sociologi-pro-svit-pisla-pandemii.html Last accessed: 25.02.2021

[11] Kishchak, T. (2020). Covid-19 ta dystantsiine navchannia u zakladakh vyshchoi osvity: analitychnyi ohliad naukovykh publikatsii z mizhnarodnykh vydan. Natsionalnyi universytet bioresursiv i pryrodokorystuvannia Ukrainy. Available at: https:// nubip.edu.ua/node/79877 Last accessed: 22.02.2021

[12] Mance, H. (2021). The future of the university in the age of Covid. Financial Times. Available at: https://www.ft.com/content/9514643d-1433-408c-8464-cb4c0e09c822

[13] Osvita i pandemiia: shcho ukraintsi dumaiut pro dystantsiine navchannia ta yak otsiniuiut ZNO (2020). Ukrainskyi kryzovyi media-tsentr. Available at: https://uacrisis.org/uk/osvita-i-pandemiya Last accessed: 22.02.2021)

[14] Rezultaty opytuvannia batkiv «Navchannia ditei pid chas karantynu» (2020). Osvitnii ombudsmen Ukrainy. Available at: https:/eo.gov.ua/wp-content/uploads/2020/04/Rezul-taty-opytuvannia-22Navchannia-ditey-pid-chas-karantynu22.pdf Last accessed: 23.02.2021 